\title{
Rooting Volume Impacts Growth, Coverage and Thermal Tolerance of Green Façade Climbing Plants
}

\author{
Pei-Wen Chung *, Stephen J. Livesley $\mathbb{C}^{\mathbb{C}}$, John P. Rayner and Claire Farrell \\ School of Ecosystem and Forestry Sciences, The University of Melbourne, 500 Yarra Boulevard, \\ Richmond, VIC 3121, Australia; sjlive@unimelb.edu.au (S.J.L.); jrayner@unimelb.edu.au (J.P.R.); \\ c.farrell@unimelb.edu.au (C.F.) \\ * Correspondence: peiwen.chung@unimelb.edu.au; Tel.: +61-402-153-268
}

Citation: Chung, P.-W.; Livesley, S.J.;

Rayner, J.P.; Farrell, C. Rooting

Volume Impacts Growth, Coverage and Thermal Tolerance of Green Façade Climbing Plants. Land 2021, 10, 1281. https://doi.org/10.3390/ land 10121281

Academic Editors: Manfred Koehler and Daniel Kaiser

Received: 28 October 2021

Accepted: 19 November 2021

Published: 23 November 2021

Publisher's Note: MDPI stays neutral with regard to jurisdictional claims in published maps and institutional affiliations.

Copyright: (c) 2021 by the authors. Licensee MDPI, Basel, Switzerland. This article is an open access article distributed under the terms and conditions of the Creative Commons Attribution (CC BY) license (https:/ / creativecommons.org/licenses/by/ $4.0 /)$.

\begin{abstract}
Green façades can provide cooling benefits through the shading of walls, evapotranspiration, and insulation. These benefits depend on good plant coverage and tolerance of heat stress. This requires sufficient rooting volume for plant growth and an adequate supply of moisture. On high-rise buildings, plants can be constrained by small rooting volumes due to engineering weight limits and cost. We assessed effects of rooting volume $(21,42$, and $63 \mathrm{~L})$ on the growth and coverage of Akebia quinata and Pandorea pandorana and leaf stress (chlorophyll fluorescence) in response to increasing air temperatures. We showed that 42 and $63 \mathrm{~L}$ rooting volumes significantly increased early plant growth and the percentage wall coverage for both species. Specific leaf area was significantly greater when grown in $63 \mathrm{~L}$ compared with $21 \mathrm{~L}$. Shoot/root ratio did not change with rooting volumes. Regardless of rooting volume, higher air temperatures on west-facing aspects led to afternoon leaf stress. In practice, for each cubic meter of rooting volume, $21 \mathrm{~m}^{2}$ (P. pandorana) and $10 \mathrm{~m}^{2}$ (A. quinata) canopy coverage can be expected within six months.
\end{abstract}

Keywords: climbing plants; evapotranspiration cooling; green façades; heat tolerance; percentage coverage; plant biomass

\section{Introduction}

Worldwide, increasing urbanisation and densification continue to have negative environmental impacts in cities, including modification of the urban climate, which leads to urban heat island effects, increased water and energy consumption, and heat-related illness and mortality [1,2]. Urban greening is used in cities to mitigate the adverse effects of increasing urbanization and to improve the environment and residents' health [3,4]. However, with urban densification, there are limited ground-level green spaces, meaning that vertical or roof-top urban greening approaches, such as green roofs and green walls, are being used [3,5]. Vertical greening of building walls can incorporate more vegetation into our cities $[6,7]$. Vertical greening can potentially provide numerous benefits, including improved air quality, increased plant diversity and habitat provision for wildlife, noise reduction, microclimate improvement, urban heat island mitigation, building thermal performance improvement, and lower energy costs, as well as improved aesthetics and psychological well-being of urban residents [8,9]. Moreover, as many of these benefits are linked to the amount of vegetation cover on buildings, as coverage increases, the positive effects of vertical greening are also increased [10]. While many diverse environmental benefits can potentially be achieved with vertical greening, one of the biggest drivers for their implementation is the cooling benefits they can provide to cities and buildings $[6,11]$. Vegetation can potentially alleviate the urban heat island effect directly through covering heat-absorbing surfaces and reducing solar gain, but also through evapotranspiration, which provides latent heat cooling benefits for the plant and the air surrounding it [12-14].

Vertical greening can be categorized as either façade greening or living walls based on their methods of growing $[15,16]$. Living wall systems grow directly into a substrate 
attached to a wall surface, whereas green façades use climbing plants such as vines, lianas, and scramblers, that grow in either ground-level substrate or in a containerised substrate, to grow up and cover a wall $[16,17]$. Green façade systems are further classified according to whether the climbing plant species are directly attached onto the walls (direct façade) or indirectly supported by the trellises, mesh, or steel cables (indirect façade) $[17,18]$. For multi-storey buildings, however, direct façades are not viable as the materials of the building wall do not provide adequate support for climbing plants to anchor or attach [17]. Therefore, indirect green façade systems are considered better for long-term multi-storey or high-rise urban greening $[19,20]$. Indirect green façades have been used in Europe since the 1880s, and have been more recently introduced to North America and Asian countries, such as Japan and Singapore [21]. It is important to research how indirect green façades should be designed so as to ensure they achieve their benefits and have widespread uptake in these new regions [22].

To support façade plant growth and coverage when grown in containers, it is important that there is an adequate substrate rooting volume (growing media) to supply water and nutrients and to provide sufficient space for root growth $[23,24]$. Inadequate rooting volumes can lead to reduced plant growth and development for woody plants such as waxapple (Syzygium samarangense (B1.) Merr. and Perry) [25] and euonymus (E. kiautschovica Loes. "Sieboldiana") [26]. Studies in natural ecosystems have shown that some woody climbing plants have deep and wide root systems to access deeply stored water $[27,28]$. However, in urban ecosystems, in order to grow woody climbing plants at successive levels of high-rise buildings, they are planted into lightweight containers with reduced rooting volumes or with lightweight substrates due to constrained load-bearing limits and costs $[29,30]$. Therefore, by limiting the substrate rooting volumes, there may be insufficient resources for climbing plants to grow well and to achieve good wall coverage [31]. In addition, under the same growing conditions, climbing plant species with different growth strategies may respond differently due to differences in growth rates [32]. To sustain rapid growth, fast-growing species have a greater capacity for resource acquisition compared to slower-growing species [32].

Few studies have evaluated the effect of the substrate rooting volume on climbing plant growth. Grapevines grown in isolated buried beds with restricted rooting volumes produced smaller trunks, shorter shoots, and lower leaf areas than those growing in field soil; despite irrigation and the fertilisers provided being sufficient for their growth [33]. The effects of reduced substrate volume on plant growth and coverage may also be more pronounced during hot summer periods, where façade plants are subject to prolonged sunlight and extreme heat. Studies have suggested that plants grown in the larger rooting volume outperform plants in the smaller rooting volume under abiotic stress [34,35]. For climbing plants to provide effective cooling, they need to develop significant vegetation coverage and volume of foliage $[10,12]$. However, a high temperature might adversely affect plant development and could lead to foliage loss, even when water is not limited; for example, birch trees dropped 33\% of leaves under heat stress [36]. Therefore, to determine the effects of rooting volume on façade growth and coverage in the first growing season, we undertook an experiment where two climbing plant species with different growth strategies were grown in three different rooting volumes (the only differentiator being container depth and not container surface area). We designed a study to answer two hypotheses, namlely: (1) restriction of rooting volume will limit plant biomass growth and rate of wall coverage even when water and nutrients are not limiting, and (2) climbing plants grown in greater rooting volumes will exhibit higher $\mathrm{Fv} / \mathrm{Fm}$ than the ones in the smaller rooting volumes under heat stress.

\section{Materials and Methods}

\subsection{Plant Materials and Growing Conditions}

Two widely-used green façade climbing plant species with different growth rates were selected for this study, namely Akebia quinata (Chocolate Vine) and Pandorea pandorana 
(Wonga Wonga Vine). Akebia quinata is a semi-deciduous twining climber with a medium growth rate that can reach up to $12 \mathrm{~m}$ in height by climbing trees [37], and is widely distributed throughout East Asia, including in China, Japan, and Korea [38]. In contrast, the second species, Pandorea pandorana, is a fast-growing evergreen twining climber that can reach up to $10 \mathrm{~m}$ in height at maturity [39], and is widespread throughout Australia [40]. There is no published information on the root growth habits of either of these climbing plant species.

Twelve uniform seedlings of both species ( 24 plants in total) were purchased from a commercial nursery (140 mm pot size, Evergreen Nursery, South Silvan, Victoria, Australia) and were transplanted into containers (Heavy duty crates, Ki-tab, Bell Dies, Sydney, Australia) with three different volumes in September 2017. These containers had the same length and width (370 $\mathrm{mm}$ long $\times 550 \mathrm{~mm}$ wide), but different depths and, as such, different volumes, namely, $21 \mathrm{~L}$ (103 mm deep), $42 \mathrm{~L}$ (206 mm deep), and $63 \mathrm{~L}$ (309 mm deep). A Scoria-based substrate was used in this experiment, which comprised of Scoria $7 \mathrm{~mm}$ aggregate $(20 \% \mathrm{v} / \mathrm{v})$, Scoria $8 \mathrm{~mm}$ minus that includes fines $(60 \% \mathrm{v} / \mathrm{v})$, and horticultural grade coir $(20 \% v / v)$. The water holding capacity and the bulk density of the substrate are $46 \%$ and $1.26 \mathrm{~g} \mathrm{~cm}^{-3}$, respectively [41].

In the nursery at the Burnley Campus, University of Melbourne, 24 climbing plants were grown on stainless steel façade supports on a north-south orientated wall. While these species can reach 10-12 m high at maturity, this height was not expected in the first growing season, especially when growing in limited rooting volumes. The supporting wall comprised three sections, each $6 \mathrm{~m} \mathrm{(W)} \mathrm{by} 2.4 \mathrm{~m}(\mathrm{H})$. The height of the existing wall was $2.4 \mathrm{~m}$, which is the standard height of a building storey according to the Australian Building Code. On each side of the wall (east and west aspect), 12 sections of stainlesssteel mesh $(1.45 \mathrm{~m}(\mathrm{~W})$ by $1.95 \mathrm{~m}(\mathrm{H})$; mesh size: $200 \mathrm{~mm} \times 340 \mathrm{~mm})$ were attached at a distance of $0.1 \mathrm{~m}$ from the wall and $0.45 \mathrm{~m}$ above the ground. This meant the plants had a $1.95 \mathrm{~m}$ structure to climb, which was sufficient during the establishment period, as the plants did not exceed the height of the structure. The experiment was a fully-randomised design, with six climbing plants of both species on east-facing and west-facing aspects of the same wall ( $n=12$, per species). Each species had at least three replicates for each rooting volume treatment. Two climate stations with data loggers (CR1000, Campbell Scientific Inc., Queensland, Australia) were used, one on the eastern aspect and one on the western aspect. These climate stations continuously recorded the irradiance (CS300 Pyranometer, Apogee Instruments Inc., Logan, UT, USA), ambient air temperature, and humidity (HMP60 Temperature and Relative Humidity Sensor, Vaisala, Helsinki, Finland). The mean values for 1 -h intervals were calculated.

The fertiliser and irrigation amounts were applied according to the rooting volume of each container, based on the standardised approach to grow containerised plants [42]. In other words, the fertiliser and irrigation applied to the 21 L rooting volume were one-third of that applied to the 63 L rooting volume. Slow release fertiliser (NPK 15.4-3.5-8.9 + trace element) (Macracote Coloniser Plus, Langley Fertilizers, Western Australia, Australia) was applied at a rate of $3.0 \mathrm{~kg} \mathrm{~m}^{-3}$ substrate (within the recommended range of application rate 2.5 to $5.5 \mathrm{~kg} \mathrm{~m}^{-3}$ ) to all rooting volume treatments at the beginning of the experiment. Irrigation was applied using drippers, at a flow rate at $0.5 \mathrm{~L} \mathrm{~min}^{-1}$ for each dripper. Two, four, and six drippers were installed for $21 \mathrm{~L}, 42 \mathrm{~L}$, and $63 \mathrm{~L}$ rooting volumes, respectively. To maintain well-watered conditions, irrigation was applied twice daily (07:00 a.m. and 17:00 p.m.) from September to November (spring) and three times daily (07:30 a.m., 14:30 p.m., and 19:30 p.m.) from December to March (summer), for 2 min each time. Daily irrigation supplies were $4 \mathrm{~L}, 8 \mathrm{~L}$, and $12 \mathrm{~L}$ during spring, and $6 \mathrm{~L}, 12 \mathrm{~L}$, and $18 \mathrm{~L}$ during summer for the three rooting volumes, respectively ( $21 \mathrm{~L}, 42 \mathrm{~L}$, and $63 \mathrm{~L})$. These irrigation volumes ensured that all three different rooting volumes were irrigated to field capacity, and the excess water was drained away after each irrigation event. All of the climbing plants were well-watered throughout the experiment and did not show signs of water deficit (as indicated by high leaf water potentials) [43]. 


\subsection{Plant Growth and Canopy Cover Measurements}

Canopy cover was measured every two months (two, four, and six months), using a high-resolution $(2760 \times 4912$ pixels $)$ digital camera to take photographs of each green façade at a fixed distance $(1.9 \mathrm{~m})$ and a fixed height $(0.9 \mathrm{~m})$ using a tripod. Photographs were taken on cloudy days with diffuse light conditions. Digital image analysis was performed to calculate the percentage of wall coverage. The background wall and climbing support were removed from the images manually using PhotoFiltre 7 (freeware, Antonio Da Cruz), and colour images of plants were then converted into binary images (black pixels only) to calculate the area of canopy cover in pixels with Image J (free software for image processing and analysis in Java) (Figure 1). Percentage coverage was the percentage of the area covered by plants to the area of wall $(1.45 \mathrm{~m}(\mathrm{~W}) \times 1.95 \mathrm{~m}(\mathrm{H}))$.

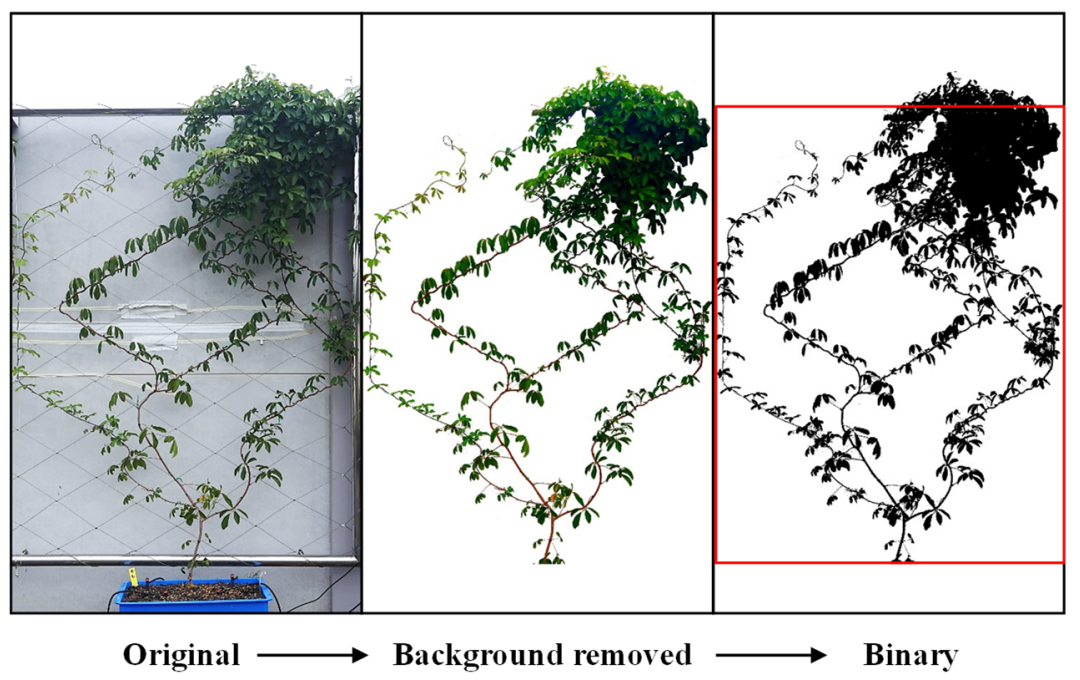

Figure 1. Image processed for measuring percentage wall coverage. The binary image (black pixels) of the same individual was used to calculate the percentage wall coverage. Red outline indicates the area of the wall $(1.45 \mathrm{~m}(\mathrm{~W}) \times 1.95 \mathrm{~m}(\mathrm{H}))$ that was examined to determine the percentage wall coverage.

The climbing plants in all rooting volume treatments were harvested in March 2018 (six months after the experiment commenced), and all plants were separated into leaves, stems, and roots. Leaf area was measured on a sub-sample of leaves ( $10 \%$ of total fresh weight). The projected leaf area (one side of the leaves) was measured using a leaf area meter (LI-3100C Area Meter, LI-COR Inc., Lincoln, NE, USA). The whole root system was excavated and cut into smaller pieces while washing away the substrate. Plant parts were oven dried $\left(70^{\circ} \mathrm{C}\right)$ for a week to obtain a dry total biomass. From these measurements, the mean values of the specific leaf area (SLA; the ratio of leaf area to leaf dry mass) and the shoot/root ratio were calculated.

\subsection{Chlorophyll Fluorescence}

Chlorophyll fluorescence is a commonly used indicator of plant stress, including extremes of temperature and light intensity [44,45]. The ratio of variable $(\mathrm{Fv}=\mathrm{Fm}-\mathrm{Fo})$ to maximal $(\mathrm{Fm})$ fluorescence of the dark-adapted leaves was measured with a portable chlorophyll fluorometer (FMS2+ Field Fluorescence Monitoring System, Hansatech Instruments), because of its rapid determination of changes in the maximum quantum efficiency of PSII photochemistry when plants are under stress [46]. The ratio of variable to maximum fluorescence $(\mathrm{Fv} / \mathrm{Fm})$ was recorded on three fully expanded mature leaves after dark adaption for 20 min. Measurements were conducted at 10:00 a.m., 13:00 p.m., and 16:00 p.m., on a hot sunny summer day. 


\subsection{Statistical Analysis}

Back-transformation was applied to the percentage wall coverage, total biomass, and total leaf area in order to ensure univariate normality before data analysis. Linear mixed models were performed in GenStat 16 (2013, VSN International Ltd., Hemel Hempstead, $\mathrm{UK}$ ), and the least significant difference (LSD at $p \leq 0.05$ ) was applied to assess the differences among pairs of treatment means within both climbing plant species. We also tested significant differences between east- and west-facing aspects for all of the variables. If the differences were insignificant, data were combined from both aspects; if significant, data were kept separate (e.g., chlorophyll fluorescence).

\section{Results}

\subsection{Climbing Plant Coverage and Growth Response to Different Rooting Volumes}

Rooting volume had no significant effect on the percentage wall coverage of either climbing plant species in the first two months after transplanting (Figure 2). However, after four months of growth, the percentage wall coverage of $P$. pandorana was significantly greater for plants with a volume of $42 \mathrm{~L}(+267.4 \%)$ or $63 \mathrm{~L}(+246.7 \%)$ compared to $21 \mathrm{~L}$ $(p<0.05)$. In contrast, there were no significant differences in percentage wall coverage of A. quinata compared with the three rooting volume treatments after four months of growth. It was not until after six months of growth that the percentage wall coverage of A. quinata was significantly greater $(+85.7 \%$ and $+105.6 \%)$ in $42 \mathrm{~L}$ or $63 \mathrm{~L}$ rooting volumes compared to $21 \mathrm{~L}(p<0.05)$. Similarly, the percentage wall coverage of $P$. pandorana was significantly greater when grown in $42(+104.2 \%)$ or $63 \mathrm{~L}(+138.3 \%)$ compared to $21 \mathrm{~L}(p<0.001)$.

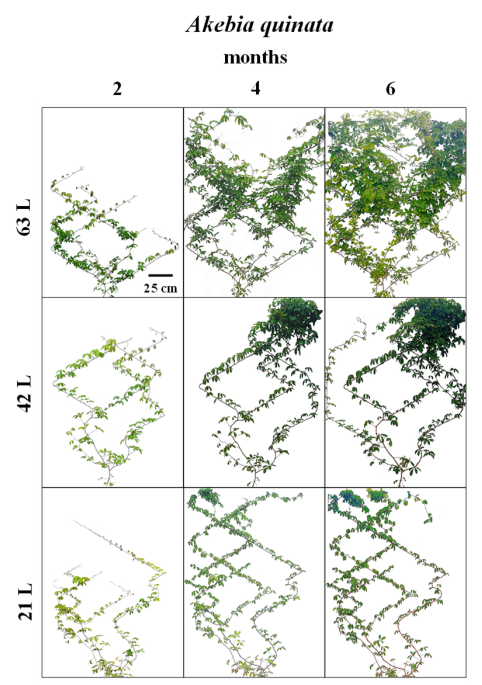

(a)

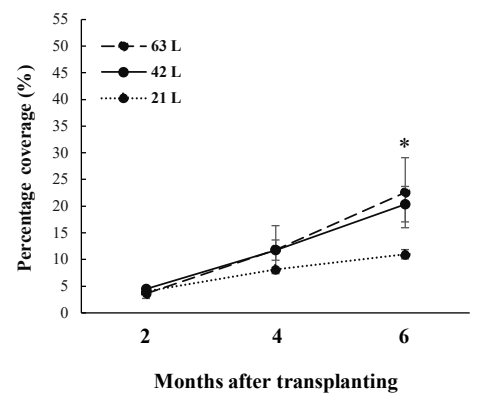

(c)

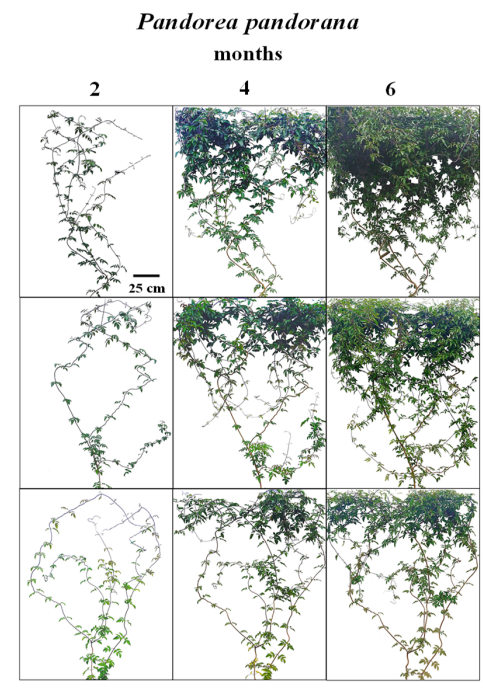

(b)

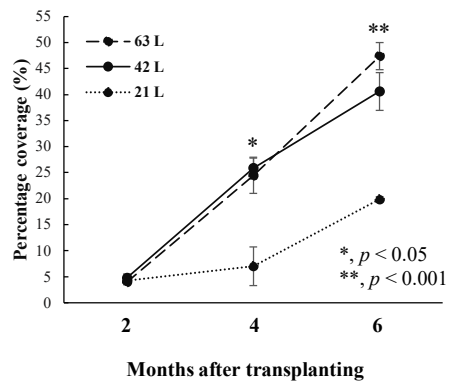

(d)

Figure 2. Percentage wall coverage of Akebia quinata $(\mathbf{a}, \mathbf{c})$ and Pandorea pandorana $(\mathbf{b}, \mathbf{d})$ grown in three different rooting volumes after two, four, and six months of growth after transplanting. Values are means \pm SE. 
The biomass growth of both climbing plants was strongly affected by the rooting volume $(p<0.001)$ (Figure 3a). The total biomass of A. quinata and P. pandorana more than doubled $(+107 \%$ and $+141 \%$, respectively) when grown in $42 \mathrm{~L}$ or $63 \mathrm{~L}$ compared with $21 \mathrm{~L}$. However, there was no significant difference in the biomass of either climbing plant species for the plants grown in $42 \mathrm{~L}$ and $63 \mathrm{~L}$ rooting volumes. After six months of growth, P. pandorana had more than double the biomass of A. quinata under the same rooting volume treatments.

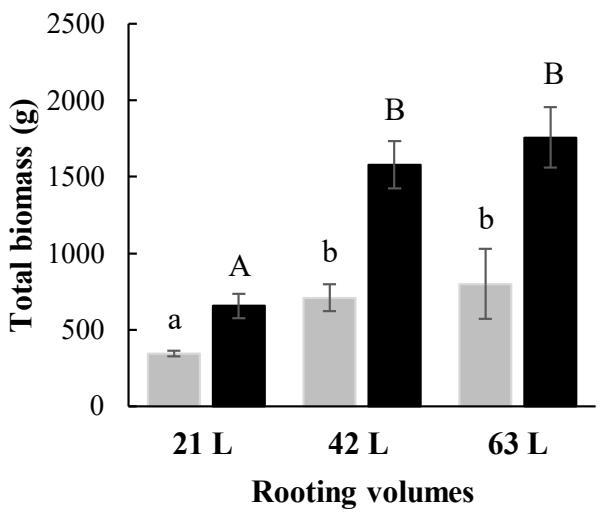

(a)

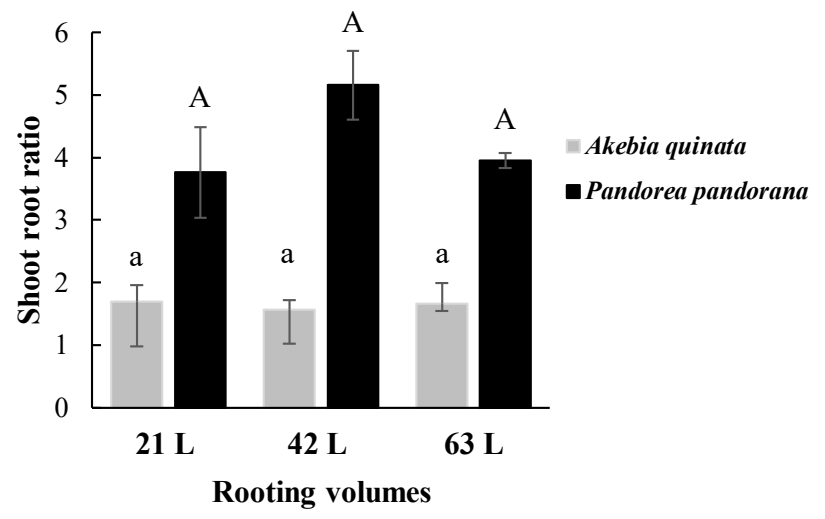

(b)

Figure 3. Average total biomass (a) and average shoot/root ratio (b) of Akebia quinata and Pandorea pandorana plants grown in three different rooting volumes after six months of growth. Values are means $\pm \mathrm{SE}$. Different letters represent significant differences within species, $p<0.001$; lowercase, Akebia quinata; capital, Pandorea pandorana.

Shoot/root biomass allocation was unaffected by rooting volume, with no significant differences for either climbing plant species (Figure $3 b$ ). However, between the two species, P. pandorana allocated more biomass to shoots than A. quinata for all of the rooting volume treatments.

The total leaf areas of A. quinata $(p<0.01)$ and P. pandorana $(p<0.001)$ were also significantly affected by the rooting volume (Figure $4 \mathrm{a}$ ). Both climbing plant species at least doubled their leaf area when grown in $42 \mathrm{~L}$ compared to $21 \mathrm{~L}$. However, there was no significant increase in leaf area of either climbing plant species between plants grown in $42 \mathrm{~L}$ and $63 \mathrm{~L}$ rooting volumes. P. pandorana had a two- or three-fold greater leaf area than A. quinata, regardless of rooting volume. Similarly, SLA increased significantly with increasing the rooting volume for both species $(p<0.001)$ (Figure $4 \mathrm{~b})$. SLA increased from 74 to $95 \mathrm{~cm}^{2} \mathrm{~g}^{-1}$ for A. quinata and from 69 to $98 \mathrm{~cm}^{2} \mathrm{~g}^{-1}$ for P. pandorana grown in $21 \mathrm{~L}$ and $63 \mathrm{~L}$, respectively.

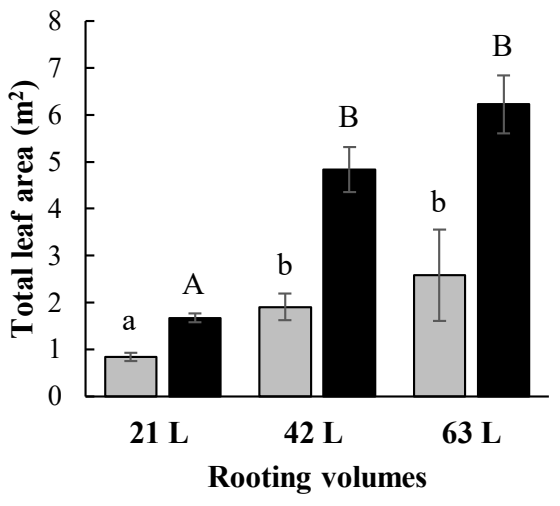

(a)

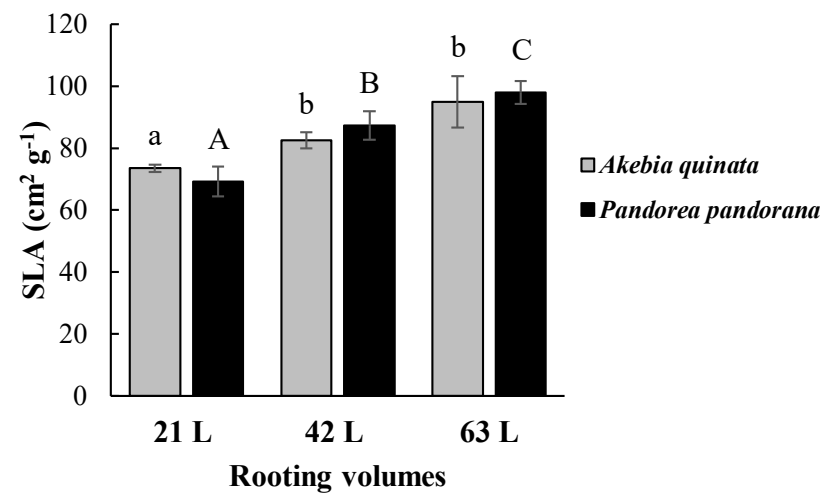

(b)

Figure 4. Average total leaf area (a) and average specific leaf area (SLA) (b) of Akebia quinata and Pandorea pandorana grown in three different rooting volumes after six months of growth. Values are means $\pm \mathrm{SE}$. Different letters represent significant differences within species, $p<0.001$; lowercase, Akebia quinata; capital, Pandorea pandorana. 


\subsection{Effects of Air Temperature and Solar Radiation on the Fv/Fm Ratio of Climbing Plants}

On a hot sunny day, on the west-facing aspect, the air temperature peaked at approximately $40{ }^{\circ} \mathrm{C}$ in the late afternoon and solar radiation peaked above $900 \mathrm{~W} \mathrm{~m}^{-2}$ (14:00 p.m.; Figure $5 b$ ), whereas on the east-facing aspect, the ambient air temperature reached a maximum of $37^{\circ} \mathrm{C}$ at midday and the solar radiation reached a maximum of $757 \mathrm{~W} \mathrm{~m}^{-2}$ (Figure 5a).

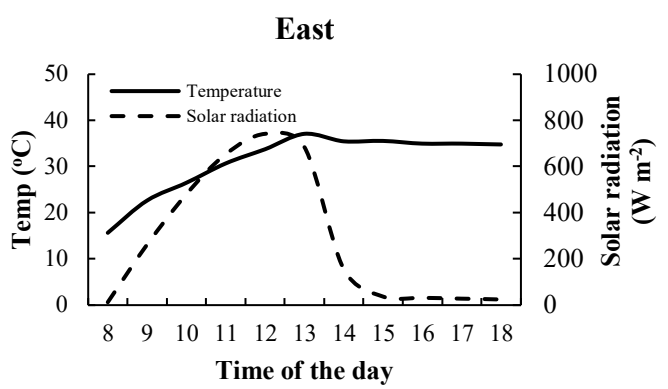

(a)

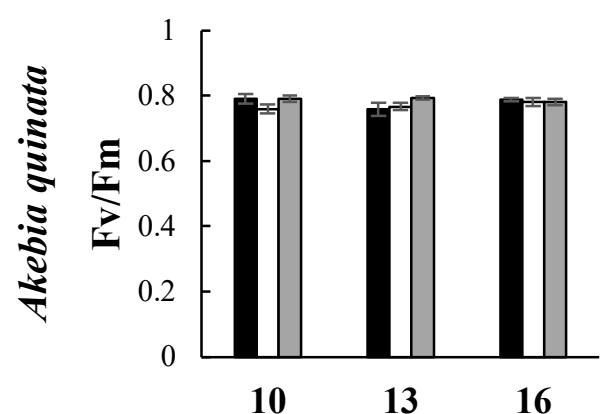

(c)

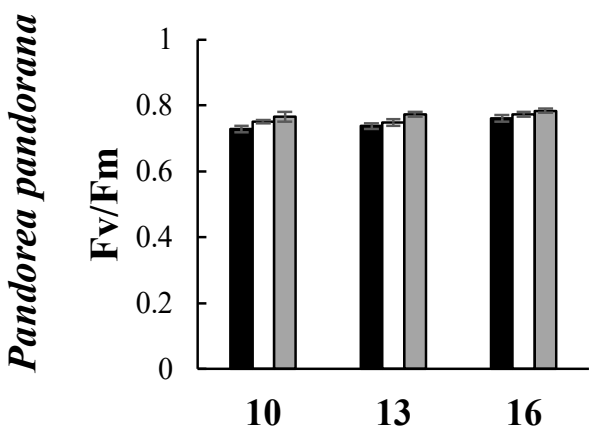

Time of the day

(e)

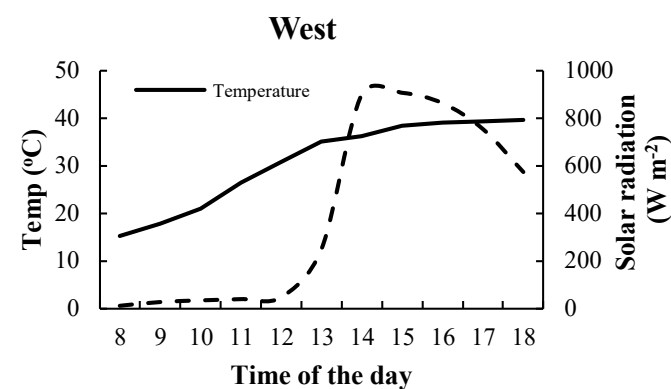

(b)

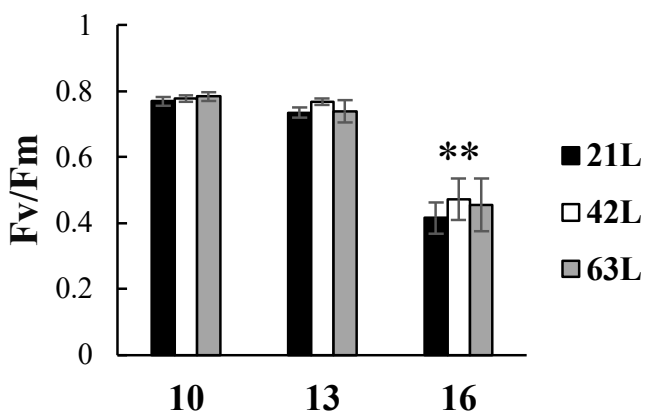

(d)

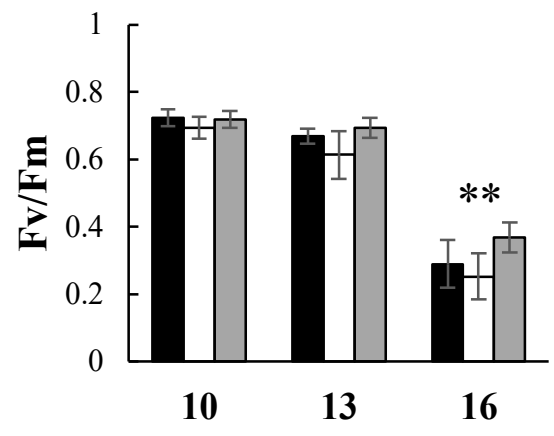

Time of the day

$* *, p<0.001$

(f)

Figure 5. Daytime changes of air temperature and solar radiation of east-facing (a) and west-facing façades (b) on a clear summer day in March 2018. Variation of the Fv/Fm ratio of Akebia quinata (c,d) and Pandorea pandorana (e,f) grown in different rooting volumes in response to the changes of air temperature and solar radiation. Values are means $\pm \mathrm{SE}$ for three different leaves.

For both climbing plant species, there was no significant effect of rooting volume on the $\mathrm{Fv} / \mathrm{Fm}$ ratio (maximum potential quantum yield of PSII) on either side of the wall at any time of day (Figure $5 \mathrm{c}-\mathrm{f}$ ). However, on the hotter west-facing side, the Fv/Fm ratios 
of both climbing plant species were significantly lower in the late afternoon (16:00 p.m.; Figure $5 \mathrm{~d}, \mathrm{f})(p<0.001)$. On the west side of the wall, the $\mathrm{Fv} / \mathrm{Fm}$ ratio decreased to a greater extent between 10:00 a.m. and 16:00 p.m. in P. pandorana ( $+49 \%$ to $+64 \%$ ) (Figure $5 \mathrm{f}$ ) compared with A. quinata ( +40 to $+46 \%$ ) (Figure $5 \mathrm{~d}$ ). In contrast, on the east-facing aspect, the $F v / F m$ ratio did not change significantly during the day as the air temperature and solar radiation changed.

\section{Discussion}

We evaluated the effects of rooting volume (the only differentiator being container depth and not container surface area) on the growth, coverage, and thermal tolerance of two climbing plant species in their first growing season. As the container surface area was constant among all three rooting volumes in this study, the morphological and physiological responses of climbing to rooting volume differences indicated sensitivity to changes in the rooting depth. We hypothesised that restriction of the rooting volume will limit plant biomass growth and rate of wall coverage while supply of water and nutrients are not limited. Our study showed that plant growth and coverage of A. quinata and P. pandorana can be significantly reduced by small rooting volumes. In general, plants grown in restricted rooting volumes have reduced shoot and root growth compared with unrestricted plants [31]. As woody climbing species tend to develop deep root systems [27,28], the small rooting volume (21 L, $103 \mathrm{~mm}$ deep) may impose physical limitations on the growth of roots and subsequently restrict the shoot growth [47].

Providing a greater rooting volume led to a significant increase in biomass and area coverage increase in both climbing plant species, which is likely due to the higher water and nutrient availability in greater rooting volumes in order to facilitate plant growth [48] Although a clustering habit of branches and foliage was observed in this study, this did not hinder plant growth. At the top of the supporting wall, branches of climbing plants spread horizontally and developed thicker foliage layers. Therefore, biomass growth and foliage development were not suppressed during the first growing season. Interestingly, a significant wall coverage response to greater rooting volumes was evident earlier for the faster growing species $P$. pandorana than for the slower growing species, A. quinata. Faster growing species can exhibit a more effective forage behaviour to acquire more water and nutrients for plant growth, and thus achieve higher growth rate [49]. It can therefore be assumed that both $42 \mathrm{~L}$ and $63 \mathrm{~L}$ rooting volumes provided sufficient resources to support the growth of these two climbing plant species for six months after transplanting. On the other hand, our results suggested that the smallest rooting volume was not suitable to grow climbing plants for indirect green façades due to the restriction of plant growth and cover.

Percentage wall coverage of façade plants has been reported as the key trait to determine the cooling effect that contributes to the thermal performance and energy savings of buildings $[13,50]$. At the end of this experiment, approximately one quarter and half of the wall areas were covered by A. quinata and P. pandorana, respectively, in both $42 \mathrm{~L}$ and $63 \mathrm{~L}$ rooting volumes. According to the relationship between the percent wall coverage and wall surface temperature reduction (WTR) investigated by Koyama et al., 2013 [13], we estimated that WTRs were 3.7 and $4.3{ }^{\circ} \mathrm{C}$ for A. quinata, and 8.3 and $9.6{ }^{\circ} \mathrm{C}$ for $P$. pandorana with $42 \mathrm{~L}$ and $63 \mathrm{~L}$ rooting volumes, respectively. Therefore, in this study, the rooting volume of $42 \mathrm{~L}$ appeared to be adequate for wall coverage and growth in the first growing season, considering there was no significant additional benefit from providing a $63 \mathrm{~L}$ rooting volume, as well as the associated economic costs and benefits of indirect green façades.

In our study, the approximate vegetation wall coverage was $1.3 \mathrm{~m}^{2}$ for P. pandorana and $0.6 \mathrm{~m}^{2}$ for $A$. quinata at the end of six months, when grown in the larger $63 \mathrm{~L}$ rooting volume (data not shown). Therefore, for every cubic metre of rooting volume, P. pandorana could achieve $21.3 \mathrm{~m}^{2}$ of wall coverage in six months. Whereas, A. quinata could achieve $10.2 \mathrm{~m}^{2}$ of wall coverage in six months per cubic metre of rooting volume. Nevertheless, these expectations are subject to the vigour and growth of the species and will change over 
time. This does not indicate the final coverage of these species. The ratio of rooting volume to canopy coverage for planting trees in urban areas has been studied [51]. However, for green façade climbing plants, no previous research has investigated the ratio of rooting volume to vegetation wall coverage.

For both climbing plant species, SLA increased with the increasing rooting volume, which is consistent with a previous study. Research showed that euonymus (E. kiautschovica Loes. "Sieboldiana") plants maintained a lower SLA than those in larger containers [26]. This is likely due to increased resource availability in greater rooting volumes as the plants from higher rainfall or nutrient-rich soils tend to have a higher SLA [52]. On the other hand, SLA is positively correlated to relative growth rate (RGR) in woody plants [53]. This may help explain the result that both climbing plant species grown in the smallest rooting volume had a relatively lower growth rate and SLA compared with those in the greater rooting volumes.

Despite the increased percentage wall coverage, biomass, and leaf area with the increased rooting volume, the allocation of biomass to shoots and roots (shoot/root ratio) was unaffected by the rooting volume. When the roots are confined in a container that restrains their development, the roots compete for essential resources [31]. With respect to the shoot/root ratio, increases in the top biomass were linearly correlated with increasing pot sizes in some woody plants, including Ilex cornuta Lindl. and Paxton, Euonymus japonica Thunb., Rhododendron x sp. [54], and Syzygium samarangense (Bl.) Merr. and Perry [25]. In contrast, other studies have demonstrated that the shoot/root ratio remaine constant as the rooting volume changed for various plant species, such as peach (Prunus persica) [55], cucumber (Cucumis sativus) [56], soybean (Glycine max (L.) Merr.) [57], salvia (Salvia splendens) [58], and euonymus (Euonymus kiautschovica Loes. "Sieboldiana") [26]. In addition, it has been reported that woody plants might be able to maintain a balance in root and shoot growth in stable environments as an adaptive mechanism to varying rooting volumes [26,59]. This is consistent with our study and may be because the provision of water and nutrients was not limited in our study, which may be the reason biomass allocation did not change among the different rooting volumes.

In contrast with our second hypothesis, climbing plants grown in the greater rooting volume did not show a higher $\mathrm{Fv} / \mathrm{Fm}$ than the ones in the smaller rooting volumes under heat stress. Regardless of rooting volume, there was a significant decrease in Fv/Fm observed in both climbing plants exposed to high ambient air temperature and high solar radiance on the west-facing aspect. During our study period, the highest ambient air temperature recorded was around $40^{\circ} \mathrm{C}$ in the late afternoon. Presumably, the decline in the $\mathrm{Fv} / \mathrm{Fm}$ ratio under heat stress might be a result of partly reversible inactivation of the PS II reaction centre $[45,60]$. A decrease in the $F v / F m$ ratio of oak trees was observed when the air temperature rose above $36{ }^{\circ} \mathrm{C}$, which caused a temporary heat-stress-dependent reduction of the leaf photosynthesis [61]. In addition, research has indicated that water bath temperature around $60^{\circ} \mathrm{C}$ led to almost complete inactivation of the PS II reaction centre in spinach and rice chloroplasts [45]. However, the decline in the Fv/Fm ratio recorded was not associated with a decrease in either plant biomass or leaf development. Although we did not measure the $\mathrm{Fv} / \mathrm{Fm}$ ratio of the same leaves the next day, it is likely that both climbing species on the west-facing aspect had recovered from heat stress after the temperature dropped at night.

This study focused mainly on the influence of rooting volume on the above-ground growth and coverage of two climbing plant species. Although the rooting behaviour of the two climbing plant species was not investigated in our study, it could be suggested that the root growth of the two climbing plant species was not limited by $42 \mathrm{~L}$ $(370 \mathrm{~mm}(\mathrm{~L}) \times 550 \mathrm{~mm}(\mathrm{~W}) \times 206 \mathrm{~mm}(\mathrm{D}))$ or $63 \mathrm{~L}(370 \mathrm{~mm}(\mathrm{~L}) \times 550 \mathrm{~mm}(\mathrm{~W}) \times 309 \mathrm{~mm}(\mathrm{D}))$ rooting volumes during the first growing season. According to Wang et al., 2001 [33], during the first year, root growth of Kyoho grapevines were not adversely affected by the restricted rooting volume, i.e., $50 \mathrm{~L}$ ( $500 \mathrm{~mm}$ long, $500 \mathrm{~mm}$ wide, and $200 \mathrm{~mm}$ deep). While we investigated the shoot/root allocation, further studies should be undertaken to assess 
the influence of limited rooting volume on root development (e.g., root density, rooting depth, and root length), as well as the long-term effects of several years on the growth and coverage of climbing plant species.

\section{Conclusions}

The aim of this study was to evaluate the effect of rooting volume on initial growth, coverage, and thermal tolerance of climbing plants for indirect green façades. Our study showed that the rooting volume affected the development of $A$. quinata and P. pandorana over the six-month period of the experiment. Significant increases in percentage wall coverage, total biomass, and leaf area of both plant species were observed in $42 \mathrm{~L}$ or $63 \mathrm{~L}$ rooting volume treatments compared with those planted in the $21 \mathrm{~L}$ rooting volume. Interestingly, a significant wall coverage response to greater rooting volumes was evident earlier for the faster growing species, P. pandorana (after four-month growth), than for the slower growing species, A. quinata (after six-month growth). In addition, the building wall area that these climbing plant species can cover when planted in to $1.0 \mathrm{~m}^{3}$ rooting volume was identified. During the first growing season, P. pandorana could provide $21.3 \mathrm{~m}^{2}$ of wall coverage, and A. quinata could achieve $10.2 \mathrm{~m}^{2}$ of wall coverage per cubic metre of rooting volume.

The SLA of both climbing plant species increased as the rooting volume increased; yet no significant difference was evident in the shoot/root ratio of either species across all rooting volume treatments. However, there were no significant differences in plant growth and coverage of either climbing plant species planted in $42 \mathrm{~L}$ and $63 \mathrm{~L}$ rooting volumes. On the other hand, the greater rooting volume did not further assist either climbing plant species under the heat stress condition. A significant decline in $F v / F m$ was observed in both climbing plants across all rooting volume treatments when exposed to high ambient air temperature and high solar radiance on the west-facing aspect in the late afternoon on a hot and dry summer day. Taken together, in this study, these results suggested that, for a wall area of $2.8 \mathrm{~m}^{2}$, these findings indicate that both $42 \mathrm{~L}$ and $63 \mathrm{~L}$ rooting volumes can provide sufficient resources to support the growth of both slower- and faster-growing climbing plant species during the first growing season for their establishments. Therefore, it could be suggested that, with a wall area of $2.8 \mathrm{~m}^{2}$, a $42 \mathrm{~L}$ rooting volume is adequate to support the plant growth and coverage of indirect green façades during the first growing season, as the $63 \mathrm{~L}$ rooting volume did not yield a material benefit when factoring in the associated economic costs and benefits of indirect green façades. While it could be expected that shallow rooting volumes would restrict climbing plant growth in this study, the effects differed according to the plant growth strategies. As both A. quinata (slower-growing) and P. pandorana (faster-growing) are commonly used climber species for green façades, their growth responses to different rooting volumes reflect different resource-use strategies, and are useful for assisting green façade design and plant selection for species with similar growth rates. To a large extent, the potential benefits of green façades depend on good plant coverage and growth. This is particularly true for containerised indirect green façades that are critically dependent on a sufficient rooting volume. Therefore, to ensure the health and performance of green façade climbing plants in the long-term, larger rooting volumes should be recommended.

Author Contributions: Conceptualization, P.-W.C., C.F., S.J.L. and J.P.R.; methodology, P.-W.C., C.F., S.J.L. and J.P.R.; software, P.-W.C., C.F. and S.J.L.; validation, P.-W.C., C.F. and S.J.L.; formal analysis, P.-W.C.; investigation, P.-W.C.; resources, C.F. and S.J.L.; data curation, P.-W.C.; writing-original draft preparation, P.-W.C.; writing-review and editing, P.-W.C., C.F., S.J.L. and J.P.R.; visualization, P.-W.C.; supervision, C.F., S.J.L. and J.P.R.; funding acquisition, P.-W.C. and C.F. All authors have read and agreed to the published version of the manuscript.

Funding: This research was funded by the research scholarships of the Frank Keenan Scholarship and Betty Elliott Horticulture Scholarship from The University of Melbourne. Pei-Wen was supported by the postgraduate scholarship from The University of Melbourne. 
Institutional Review Board Statement: Not applicable.

Informed Consent Statement: Not applicable.

Data Availability Statement: Data available on request due to restrictions e.g., privacy or ethical.

Acknowledgments: We are thankful for the research scholarships, namely the Frank Keenan Scholarships and Betty Elliott Horticulture Scholarship, for supporting this study. We thank Hsiao-Hsuan Chu, Carola Pritzkow Peter Somerville, Pengzhen Du, and Janina Konarska for assistance in harvesting plants, as well as Audrey Michenaud-Rague who helped through the entire experimental period. We are grateful for the technical support and assistance kindly provided by the Burnley nursery staff Nick Osborne and Sascha Andrusiak. Pei-Wen was supported by the postgraduate scholarship from The University of Melbourne.

Conflicts of Interest: The authors declare no conflict of interest.

\section{References}

1. Bambrick, H.J.; Capon, A.G.; Barnett, G.B.; Beaty, R.M.; Burton, A.J. Climate change and health in the urban environment: Adaptation opportunities in Australian cities. Asia Pac. J. Public Health 2011, 23, 67S-79S. [CrossRef] [PubMed]

2. Oleson, K.; Monaghan, A.; Wilhelmi, O.; Barlage, M.; Brunsell, N.; Feddema, J.; Hu, L.; Steinhoff, D. Interactions between urbanization, heat stress, and climate change. Clim. Chang. 2015, 129, 525-541. [CrossRef]

3. Manso, M.; Teotónio, I.; Silva, C.M.; Cruz, C.O. Green roof and green wall benefits and costs: A review of the quantitative evidence. Renew. Sustain. Energy Rev. 2021, 135, 110111. [CrossRef]

4. Pérez-Urrestarazu, L.; Fernández-Cañero, R.; Franco-Salas, A.; Egea, G. Vertical greening systems and sustainable cities. J. Urban Technol. 2015, 22, 65-85. [CrossRef]

5. Haaland, C.; van Den Bosch, C.K. Challenges and strategies for urban green-space planning in cities undergoing densification: A review. Urban For. Urban Green. 2015, 14, 760-771. [CrossRef]

6. Hunter, A.M.; Williams, N.S.; Rayner, J.P.; Aye, L.; Hes, D.; Livesley, S.J. Quantifying the thermal performance of green façades: A critical review. Ecol. Eng. 2014, 63, 102-113. [CrossRef]

7. Shamanga, K.J.; Idris, H.A.; Babangida, A. Integrating Green Wall in Healthcare Buildings to Curb Climate Change. J. Eng. Comput. Appl. Sci. (JECAS) 2021, 5. Available online: https://journal.gjbeacademia.com/index.php/jecas/article/view/8 (accessed on 26 October 2021).

8. Medl, A.; Stangl, R.; Florineth, F. Vertical greening systems-a review on recent technologies and research advancement. Build. Environ. 2017, 125, 227-239. [CrossRef]

9. Tudiwer, D.; Korjenic, A. The effect of living wall systems on the thermal resistance of the façade. Energy Build. 2017, 135, 10-19. [CrossRef]

10. Cameron, R.W.; Taylor, J.E.; Emmett, M.R. What's 'cool' in the world of green façades? How plant choice influences the cooling properties of green walls. Build. Environ. 2014, 73, 198-207. [CrossRef]

11. Bustami, R.A.; Belusko, M.; Ward, J.; Beecham, S. Vertical greenery systems: A systematic review of research trends. Build. Environ. 2018, 146, 226-237. [CrossRef]

12. Hoelscher, M.-T.; Nehls, T.; Jänicke, B.; Wessolek, G. Quantifying cooling effects of facade greening: Shading, transpiration and insulation. Energy Build. 2016, 114, 283-290. [CrossRef]

13. Koyama, T.; Yoshinaga, M.; Hayashi, H.; Maeda, K.-i.; Yamauchi, A. Identification of key plant traits contributing to the cooling effects of green façades using freestanding walls. Build. Environ. 2013, 66, 96-103. [CrossRef]

14. Vox, G.; Blanco, I.; Schettini, E. Green façades to control wall surface temperature in buildings. Build. Environ. 2018, 129, 154-166. [CrossRef]

15. Besir, A.B.; Cuce, E. Green roofs and facades: A comprehensive review. Renew. Sustain. Energy Rev. 2018, 82, 915-939. [CrossRef]

16. Fernández-Cañero, R.; Urrestarazu, L.P.; Perini, K. Vertical Greening Systems: Classifications, Plant Species, Substrates. In Nature Based Strategies for Urban and Building Sustainability; Elsevier: Oxford, UK, 2018; pp. 45-54.

17. Manso, M.; Castro-Gomes, J. Green wall systems: A review of their characteristics. Renew. Sustain. Energy Rev. 2015, 41, 863-871. [CrossRef]

18. Jim, C.Y. Greenwall classification and critical design-management assessments. Ecol. Eng. 2015, 77, 348-362. [CrossRef]

19. Teotónio, I.; Silva, C.M.; Cruz, C.O. Economics of green roofs and green walls: A literature review. Sustain. Cities Soc. 2021, 69, 102781. [CrossRef]

20. Thottathi, V.; Balamuralikrishna, C.; Ghosh, S. Use of Green Facades In Sustainable Building Environments: Quantifying the Uptake Rates of Air Pollutants by Facades Draped with Tropical Creepers. In Proceedings of the International Conference on Sustainable Built Environment (ICSBE-2010), Kandy, Sri Lanka, 13-14 December 2010; pp. 363-373.

21. Köhler, M. Green facades—a view back and some visions. Urban Ecosyst. 2008, 11, 423-436. [CrossRef]

22. Ascione, F.; De Masi, R.F.; Mastellone, M.; Ruggiero, S.; Vanoli, G.P. Green walls, a critical review: Knowledge gaps, design parameters, thermal performances and multi-criteria design approaches. Energies 2020, 13, 2296. [CrossRef]

23. Dunnett, N.; Kingsbury, N. Planting Green Roofs and Living Walls; Timber Press: Portland, OR, USA, 2008. 
24. Growing Green Guide: A Guide to Green Roofs, Walls and Facades in Melbourne and Victoria, Australia; Department of Environment and Primary Industries: Melbourne, Victoria, Australia, 2014.

25. Hsu, Y.; Tseng, M.; Lin, C. Container volume affects growth and development of wax-apple. HortScience 1996, $31,1139-1142$. [CrossRef]

26. Dubik, S.P.; Krizek, D.T.; Stimart, D.P.; McIntosh, M.S. Growth analysis of spreading euonymus subjected to root restriction. J. Plant Nutr. 1992, 15, 469-486. [CrossRef]

27. Andrade, J.L.; Meinzer, F.C.; Goldstein, G.; Schnitzer, S.A. Water uptake and transport in lianas and co-occurring trees of a seasonally dry tropical forest. Trees 2005, 19, 282-289. [CrossRef]

28. Schnitzer, S.A. A mechanistic explanation for global patterns of liana abundance and distribution. Am. Nat. 2005, 166, 262-276. [CrossRef] [PubMed]

29. Haege, E.; Leake, S. Soils for Landscape Development: Selection, Specification and Validation; Csiro Publishing: Melbourne, Australia, 2014.

30. Handreck, K.A.; Black, N.D. Growing Media for Ornamental Plants and Turf, 4th ed.; UNSW Press: Sydney, Australia, 2010.

31. NeSmith, D.S.; Duval, J.R. The effect of container size. HortTechnology 1998, 8, 495-498. [CrossRef]

32. Lambers, H.; Poorter, H. Inherent Variation in Growth Rate Between Higher Plants: A Search for Physiological Causes and Ecological Consequences. In Advances in Ecological Research; Elsevier: Cambridge, MA, USA, 1992; Volume 23, pp. 187-261.

33. Wang, S.; Okamoto, G.; Hirano, K.; Lu, J.; Zhang, C. Effects of restricted rooting volume on vine growth and berry development of Kyoho grapevines. Am. J. Enol. Vitic. 2001, 52, 248-253.

34. Aghai, M.M.; Pinto, J.R.; Davis, A.S. Container volume and growing density influence western larch (Larix occidentalis Nutt.) seedling development during nursery culture and establishment. New For. 2014, 45, 199-213. [CrossRef]

35. Villar-Salvador, P.; Puértolas, J.; Cuesta, B.; Penuelas, J.L.; Uscola, M.; Heredia-Guerrero, N.; Benayas, J.M.R. Increase in size and nitrogen concentration enhances seedling survival in Mediterranean plantations. Insights from an ecophysiological conceptual model of plant survival. New For. 2012, 43, 755-770. [CrossRef]

36. Darbah, J.N.; Sharkey, T.D.; Calfapietra, C.; Karnosky, D.F. Differential response of aspen and birch trees to heat stress under elevated carbon dioxide. Environ. Pollut. 2010, 158, 1008-1014. [CrossRef] [PubMed]

37. Brunel, S.; Schrader, G.; Brundu, G.; Fried, G. Emerging invasive alien plants for the Mediterranean Basin. EPPO Bull. 2010, 40, 219-238. [CrossRef]

38. Yen, N.T.; Thu, N.V.; Zhao, B.T.; Lee, J.H.; Kim, J.A.; Son, J.K.; Choi, J.S.; Woo, E.R.; Woo, M.H.; Min, B.S. Quantitative determination of compounds from Akebia quinata by high-performance liquid chromatography. Bull. Korean Chem. Soc. 2014, 35, 1956-1964. [CrossRef]

39. Andresen, L. High impact bush regeneration: Is there a role for heavy machinery? Australas. Plant Conserv. J. Aust. Netw. Plant Conserv. 2012, 21, 9-11.

40. James, E.; Knox, R. Reproductive-biology of the Australian species of the genus Pandorea (Bignoniaceae). Aust. J. Bot. 1993, 41, 611-626. [CrossRef]

41. Farrell, C.; Mitchell, R.; Szota, C.; Rayner, J.; Williams, N. Green roofs for hot and dry climates: Interacting effects of plant water use, succulence and substrate. Ecol. Eng. 2012, 49, 270-276. [CrossRef]

42. Wilkinson, K.M.; Landis, T.D.; Haase, D.L.; Daley, B.F.; Dumroese, R.K. Tropical Nursery Manual: A Guide to Starting and Operating a Nursery for Native and Traditional Plants. In Agriculture Handbook 732; US Department of Agriculture, Forest Service: Washington, DC, USA, 2014.

43. Chung, P.-W. The Effects of Rooting Volume, Greywater Irrigation and Reduced Sunlight on Climbing Plants for Indirect Green Façades in Urban Environments. Ph.D. Thesis, The University of Melbourne, Melbourne, Australia, 31 January 2021.

44. Dias, D.P.; Marenco, R.A. Fluorescence characteristics and photoinhibition in saplings of manwood on clear days and under overcast conditions. Sci. Agric. 2007, 64, 595-600. [CrossRef]

45. Yamane, Y.; Kashino, Y.; Koike, H.; Satoh, K. Increases in the fluorescence Fo level and reversible inhibition of Photosystem II reaction center by high-temperature treatments in higher plants. Photosynth. Res. 1997, 52, 57-64. [CrossRef]

46. Maxwell, K.; Johnson, G.N. Chlorophyll fluorescence-a practical guide. J. Exp. Bot. 2000, 51, 659-668. [CrossRef] [PubMed]

47. McConnaughay, K.; Bazzaz, F. Is physical space a soil resource? Ecology 1991, 72, 94-103. [CrossRef]

48. Kostopoulou, P.; Radoglou, K.; Dini-Papanastasi, O.; Adamidou, C. Effect of mini-plug container depth on root and shoot growth of four forest tree species during early developmental stages. Turk. J. Agric. For. 2011, 35, 379-390.

49. Fransen, B.; de Kroon, H.; De Kovel, C.; van den Bosch, F. Disentangling the effects of root foraging and inherent growth rate on plant biomass accumulation in heterogeneous environments: A modelling study. Ann. Bot. 1999, 84, 305-311. [CrossRef]

50. Perez, G.; Rincon, L.; Vila, A.; Gonzalez, J.M.; Cabeza, L.F. Green vertical systems for buildings as passive systems for energy savings. Appl. Energy 2011, 88, 4854-4859. [CrossRef]

51. Kent, D.; Shultz, S.; Wyatt, T.; Halcrow, D. Soil volume and tree condition in Walt Disney World parking lots. Landsc. J. 2006, 25, 94-107. [CrossRef]

52. Wright, I.J.; Reich, P.B.; Westoby, M. Strategy shifts in leaf physiology, structure and nutrient content between species of high-and low-rainfall and high-and low-nutrient habitats. Funct. Ecol. 2001, 15, 423-434. [CrossRef]

53. Antúnez, I.; Retamosa, E.C.; Villar, R. Relative growth rate in phylogenetically related deciduous and evergreen woody species. Oecologia 2001, 128, 172-180. [CrossRef] 
54. Keever, G.; Cobb, G.; Reed, R. Effects of container dimension and volume on growth of three woody ornamentals. HortScience 1985, 20, 89-93.

55. Rieger, M.; Marra, F. Responses of young peach trees to root confinement. J. Am. Soc. Hortic. Sci. 1994, 119, 223-228. [CrossRef]

56. Robbins, N.S.; Pharr, D.M. Effect of restricted root growth on carbohydrate metabolism and whole plant growth of Cucumis sativus L. Plant Physiol. 1988, 87, 409-413. [CrossRef]

57. Krizek, D.T.; Carmi, A.; Mirecki, R.M.; Snyder, F.W.; Bunce, J.A. Comparative effects of soil moisture stress and restricted root zone volume on morphogenetic and physiological responses of soybean [Glycine max (L.) Merr.]. J. Exp. Bot. 1985, 36, 25-38. [CrossRef]

58. Van Iersel, M. Root restriction effects on growth and development of salvia (Salvia splendens). HortScience 1997, 32, 1186-1190. [CrossRef]

59. Kramer, P.J.; Kozlowski, T.T. Physiology of Woody Plants; Academic Press: New York, NY, USA, 1979.

60. Camejo, D.; Rodríguez, P.; Morales, M.A.; Dell'Amico, J.M.; Torrecillas, A.; Alarcón, J.J. High temperature effects on photosynthetic activity of two tomato cultivars with different heat susceptibility. J. Plant Physiol. 2005, 162, 281-289. [CrossRef] [PubMed]

61. Haldimann, P.; Feller, U. Inhibition of photosynthesis by high temperature in oak (Quercus pubescens L.) leaves grown under natural conditions closely correlates with a reversible heat-dependent reduction of the activation state of ribulose-1, 5-bisphosphate carboxylase/oxygenase. Plant Cell Environ. 2004, 27, 1169-1183. [CrossRef] 